\title{
Induction of aromatic ring: cleavage dioxygenases in Stenotrophomonas maltophilia strain KB2 in cometabolic systems
}

\author{
Danuta Wojcieszyńska • Urszula Guzik • \\ Izabela Greń • Magdalena Perkosz • \\ Katarzyna Hupert-Kocurek
}

Received: 28 May 2010/ Accepted: 27 July 2010/Published online: 10 August 2010

(C) The Author(s) 2010. This article is published with open access at Springerlink.com

\begin{abstract}
Stenotrophomonas maltophilia $\mathrm{KB} 2$ is known to produce different enzymes of dioxygenase family. The aim of our studies was to determine activity of these enzymes after induction by benzoic acids in cometabolic systems with nitrophenols. We have shown that under cometabolic conditions KB2 strain degraded $0.25-0.4 \mathrm{mM}$ of nitrophenols after 14 days of incubation. Simultaneously degradation of $3 \mathrm{mM}$ of growth substrate during 1-3 days was observed depending on substrate as well as cometabolite used. From cometabolic systems with nitrophenols as cometabolites and 3,4-dihydroxybenzoate as a growth substrate, dioxygenases with the highest activity of protocatechuate 3,4-dioxygenase were isolated. Activity of catechol 1,2- dioxygenase and protocatechuate 4,5-dioxygenase was not observed. Catechol 2,3-dioxygenase was active only in cultures with 4-nitrophenol. Ability of KB2 strain to induce and synthesize various dioxygenases depending on substrate present in medium makes this strain useful in bioremediation of sites contaminated with different aromatic compounds.
\end{abstract}

Keywords Nitrophenols - Cometabolism - Dioxygenase · Induction

\section{Introduction}

Under aerobic conditions aromatic compounds, with the exception of those with deactivated substituent group,

D. Wojcieszyńska · U. Guzik ( $₫)$ · I. Greń · M. Perkosz ·

K. Hupert-Kocurek

Faculty of Biology and Environment Protection,

Department of Biochemistry, University of Silesia,

Jagiellonska 28, 40-032 Katowice, Poland

e-mail: urszula.guzik@us.edu.pl undergo degradation through oxygenetic ring fission by catechol 1,2- or 2,3-dioxygenase as well as protocatechuate 3,4- or 4,5-dioxygenase. Presence of deactivated substituents with strong electrophilic properties makes the attack of oxygen on aromatic ring impossible (Pitter 1985). Since the nitro group is a powerful deactivating substituent aerobic degradation of these substrates occurs generally through the reduction as well as regrouping and elimination of the nitrate group following aromatic ring cleavage (Blasco et al. 1999; Schenzle et al. 1997). Transformation of polynitrated aromatic compounds by $\mathrm{F}_{420}$-dependent enzymatic complex and hydride $\delta$-complex formation was also shown (Ebert et al. 1999). Some microorganisms degrade nitrophenols through aromatic ring fission by dioxygenases without prior removal of the nitrate group. However degradation of nitrophenols occurs most often through their hydroxylation to benzenotriol, which is the ring fission substrate for hydroquinone 1,2-dioxygenase (Chauhan et al. 2000; Pakala et al. 2007), Walia et al. (2002) have shown activity of nitrocatechol 2,3- dioxygenase catalyzing transformation of 4-nitrocatechol into 3-nitro-2-hydroxy-6-oxo-hexa-2,4-dienoic acid in Pseudomonas putida strain. In other study Kieboom et al. (2001) have observed induction of 2,3- dioxygenase in Nocardia strain S3 in the presence of 3-nitrocatechol. It has been shown that this enzyme exhibits absolute specificity to catechol C-3 substituents (Kieboom et al. 2001) and clearly suggests dependence between inductor and the activity of 2,3- dioxygenase. Cassidy et al. (1999) observed degradation of nitrophenols by Sphingomonas sp. strain UG30 after induction of hydroquinone dioxygenase by pentachlorophenol. Pentachlorophenol-induced enzyme transformed benzenotriol formed during $p$-nitrophenol degradation.

Because of high toxicity and resistance to biodegradation, mononitrophenols are insufficient source of carbon and energy for microorganisms and degradation of these 
compounds requires presence of additional growth substrate, which increases biomass concentration and stimulates degradation of toxic chemicals. As the compounds similar in structure to transformed nitroaromatics accelerate their degradation, for mononitrophenols degradation other phenolic compounds are frequently used as growth substrate (Cho et al. 2000; Leung et al. 1997, 1999; Wan et al. 2007).

In previous works activity of various dioxygenases isolated from strain KB2 together with the ability of this strain to cometabolic transformation of nitroaromatics was observed (Greń et al. 2010; Guzik et al. 2009). Therefore in the present work an attempt to determine activity level of dioxygenases after their induction by different aromatic compounds was made. The main aim of this work was to check the activity of dioxygenases isolated from cultures with nitrophenols and verification how cometabolic conditions influenced synthesis of these enzymes.

\section{Methods}

Bacterial strain and growth conditions

Strain KB2 is a gram-negative, aromatic compoundsdegrading bacterium that was isolated from activated sludge of a sewage treatment plant in Bytom-Miechowice in Poland as described previously (Guzik et al. 2009). On the basis of morphological and physiochemical characteristics and 16S rRNA gene sequence analysis was identified as Stenotrophomonas maltophilia (NCBI accession number DQ230920).

Liquid cultures of Stenotrophomonas maltophilia strain KB2 were grown in mineral salts medium (MSM) contained $3.78 \mathrm{~g} \mathrm{Na}_{2} \mathrm{HPO}_{4} \cdot 12 \mathrm{H}_{2} \mathrm{O}, 0.5 \mathrm{~g} \mathrm{KH}_{2} \mathrm{PO}_{4}, 5 \mathrm{~g} \mathrm{NH} 4 \mathrm{Cl}$, $0.2 \mathrm{~g} \mathrm{MgSO}_{4} \cdot 7 \mathrm{H}_{2} \mathrm{O}, 0.01 \mathrm{~g}$ yeast extract and $1 \mathrm{ml}$ of trace element solution (TES) per liter. TES contained $3.82 \mathrm{~g}$ $\mathrm{FeSO}_{4} \cdot 7 \mathrm{H}_{2} \mathrm{O}, 0.3 \mathrm{~g} \mathrm{CoSO}_{4} \cdot 7 \mathrm{H}_{2} \mathrm{O}, 0.08 \mathrm{~g} \mathrm{MnSO}_{4} \cdot \mathrm{H}_{2} \mathrm{O}$, $0.14 \mathrm{~g} \mathrm{ZnSO}_{4} \cdot 7 \mathrm{H}_{2} \mathrm{O}, 0.006 \mathrm{~g} \mathrm{H}_{3} \mathrm{BO}_{3}, 0.04 \mathrm{NaMoO}_{4} \cdot 2 \mathrm{H}_{2} \mathrm{O}$, $0.08 \mathrm{~g} \quad \mathrm{NiSO}_{4} \cdot 7 \mathrm{H}_{2} \mathrm{O}, \quad 0.003 \mathrm{~g} \quad \mathrm{CuSO}_{4} \cdot 5 \mathrm{H}_{2} \mathrm{O}, \quad 0.15 \mathrm{~g}$ $\mathrm{Al}_{2}\left(\mathrm{SO}_{4}\right)_{3} \cdot 18 \mathrm{H}_{2} \mathrm{O}, 0.006 \mathrm{Na}_{2} \mathrm{WO}_{4} \cdot 2 \mathrm{H}_{2} \mathrm{O}, 10 \mathrm{ml} 32 \% \mathrm{HCl}$ in 11 of the solution. The $\mathrm{pH}$ was adjusted to 7.1.

In studies on cometabolic transformation of nitrophenols, as well as induction of enzymes, $3 \mathrm{mM}$ benzoate (BA), 4-hydroxybenzoate (4-HB), 3,4-dihydroxybenzoate (3,4-DHB) as growth substrates and 2-nitrophenol (2-NP), 3-nitrophenol (3-NP) or 4-nitrophenol (4-NP) in concentration $1 \mathrm{mM}$, as cometabolites, were used. Stock solutions of benzoate $(20 \mathrm{mM})$, 4-hydroxybenzoate $(20 \mathrm{mM})$, 3,4-dihydroxybenzoate (20 mM), 2-nitrophenol (10 mM), 3-nitrophenol (10 mM) or 4-nitrophenol (10 mM) were prepared in distilled water.

Cells were proliferated in mineral medium with $3 \mathrm{mM}$ of phenol (at $30^{\circ} \mathrm{C}$ on a rotary shaker at $130 \mathrm{rpm}$ ), harvested by centrifugation $\left(5,000 \times g\right.$ at $4^{\circ} \mathrm{C}$ for $\left.15 \mathrm{~min}\right)$ and washed with fresh sterile medium. Cells prepared in such a way were used as inoculum. Cultures in sterile mineral salt medium supplemented with $3 \mathrm{mM}$ growth substrates and $1 \mathrm{mM}$ of cometabolite were inoculated with previously prepared cells to the final optical density about 0.1 in absorbance scale at $\lambda=600 \mathrm{~nm}$, and incubated at $30^{\circ} \mathrm{C}$ with shaking at $130 \mathrm{rpm}$. Suitable growth substrate (benzoate, 4-hydroxybenzoate, 3,4-dihydroxybenzoate) was introduced into the culture every $72 \mathrm{~h}$. All cultures were grown in triplicates.

\section{Bacterial growth determination}

In cultures enriched with nitrophenols culture density was determined indirectly using modified method of Bradford (1976). $0.5 \mathrm{ml}$ of culture was mixed with $0.5 \mathrm{ml} \mathrm{KOH}$ and incubated at $100^{\circ} \mathrm{C}$ for $10 \mathrm{~min}$. After cooling, $0.2 \mathrm{ml}$ of solution were taken, mixed with $1.0 \mathrm{ml}$ of Bradford reagent and incubated for $10 \mathrm{~min}$. Absorbance of sample was measured at $595 \mathrm{~nm}$. Bovine serum albumin was used as a standard.

\section{Substrate determination}

Culture supernatant was prepared by centrifugation $\left(10,000 \times g\right.$ at $4^{\circ} \mathrm{C}$ for $\left.20 \mathrm{~min}\right)$ Concentration of aromatic compounds in the culture supernatant was determined by HPLC (Merck HITACHI) equipped with a LiChromospher ${ }^{\circledR}$ RP-18 column $(4 \times 250 \mathrm{~mm})$ and a DAD detector (Merck HITACHI). The wavelength for detection of substrates, composition of eluent and solvent, as well as the flow rate, were developed separately for each aromatic compound. The mobile phase, in mononitrophenols and benzoic acid determination, was acetonitryl and $1 \%$ acetic acid $(40: 60 \mathrm{v} / \mathrm{v})$ at the flow rate of $1 \mathrm{ml} \mathrm{min}^{-1}$. 4-HB was separated in methanol:1\% acetic acid (60:40 v/v) as a mobile phase, at the flow rate of $0.8 \mathrm{ml} \mathrm{min}^{-1}$. For separation of 3,4-DHB methanol:1\% acetic acid (30:70 v/v) at the flow rate of $0.8 \mathrm{ml} \mathrm{m^{-1 }}$ was used. The detection wavelength was set at $260 \mathrm{~nm}$. Chemical compounds in the supernatant were identified and quantified by comparing HPLC retention times and UV-visible spectra with those of external standards. Concentration of mononitrophenols as well as benzoic acids was expressed in $\mathrm{mM}$ and determined by peak area calculations. Data were corrected by substraction of abiotic degradation of aromatic compounds.

Preparation of cell extracts

Cells of Stenotrophomonas maltophilia strain KB2 were harvested after 7 days of culture by centrifugation $(4,500 \mathrm{~g}$ 
for $15 \mathrm{~min}$ at $4^{\circ} \mathrm{C}$ ) and the pellet was washed with $50 \mathrm{mM}$ phosphate buffer, $\mathrm{pH}$ 7.0, and resuspended in the same buffer. Cell-free extracts were prepared by sonication of the whole cell suspension (6 times for $15 \mathrm{~s}$ ) and centrifugation at $9,000 \mathrm{~g}$ for $30 \mathrm{~min}$ at $4^{\circ} \mathrm{C}$. Clear supernatant was used as a crude cell extract for enzyme assays.

\section{Enzyme assays}

Activity of catechol 1,2-dioxygenase [EC 1.13.11.1] was measured spectrophotometrically by formation of cis, cismuconic acid at $260 \mathrm{~nm}\left(\lambda_{260}=16,800 \mathrm{M}^{-1} \mathrm{~cm}^{-1}\right)$. The reaction mixture contained $20 \mu \mathrm{l}$ of catechol $(50 \mathrm{mM})$, $67 \mu \mathrm{l} \mathrm{Na}{ }_{2}$ EDTA $(20 \mathrm{mM}), 893 \mu \mathrm{l}$ of phosphoric buffer $\mathrm{pH}$ $7.4(50 \mathrm{mM})$ and $20 \mu \mathrm{l}$ of crude enzyme extracts in a total volume of $1 \mathrm{ml}$. When activity of catechol 2,3-dioxygenase was detected, crude enzyme extract was incubated with $5 \%$ $\mathrm{H}_{2} \mathrm{O}_{2}$ prior to determination of catechol 1,2-dioxygenase. In order to determine catechol 2,3-dioxygenase [EC 1.13.11.2] activity, formation of 2-hydroxymuconic semialdehyde was measured at $375 \mathrm{~nm}\left(\lambda_{375}=36,000 \mathrm{M}^{-1} \mathrm{~cm}^{-1}\right)$. The reaction mixture contained $20 \mu$ of catechol $(50 \mathrm{mM})$, $960 \mu \mathrm{l}$ of phosphoric buffer $\mathrm{pH} 7.4(50 \mathrm{mM})$ and $20 \mu \mathrm{l}$ of crude extract in a total volume of $1 \mathrm{ml}$ (Hegeman 1966). Activity of protocatechuate 3,4-dioxygenase [EC 1.13.11.3] was measured by protocatechuate depletion at $290 \mathrm{~nm}$ in a reaction mixture containing $20 \mu \mathrm{l}$ of protocatechuate (50 mM), $960 \mu \mathrm{l}$ of Tris-HCl buffer $\mathrm{pH} 7.4(50 \mathrm{mM})$ and $20 \mu \mathrm{l}$ of crude extract in a total volume of $1 \mathrm{ml}$. A molar extinction coefficient of $2,300 \mathrm{M}^{-1} \mathrm{~cm}^{-1}$ was used, which is the difference between $\lambda_{290}$ of protocatechuate $\left(3,890 \mathrm{M}^{-1} \mathrm{~cm}^{-1}\right)$ and $\lambda_{290}$ of the product 3-carboxycis cis-muconate $\left(1,590 \mathrm{M}^{-1} \mathrm{~cm}^{-1}\right)$. Protocatechuate 4,5-dioxygenase [EC 1.13.11.8] activity was measured spectrophotometrically by formation of 2-hydroxy-4-carboxymuconic semialdehyde at $410 \mathrm{~nm} \quad\left(\lambda_{410}=9,700\right.$ $\mathrm{M}^{-1} \mathrm{~cm}^{-1}$ ). The reaction mixture contained $20 \mu \mathrm{l}$ of protocatechuate $(50 \mathrm{mM}), 960 \mu \mathrm{l}$ of Tris- $\mathrm{HCl}$ buffer $\mathrm{pH} 7.4$ $(50 \mathrm{mM})$ and $20 \mu \mathrm{l}$ of crude extract in a total volume of $1 \mathrm{ml}$ (Stanier and Ingraham 1954). In order to determine hydroxyquinol 1,2-dioxygenase [EC 1.13.11.37] activity, the formation of 4-hydroxymuconic semialdehyde was measured at $320 \mathrm{~nm}\left(\lambda_{320}=11 \mathrm{mM}^{-1} \mathrm{~cm}^{-1}\right)$. The reaction mixture contained $200 \mu \mathrm{l}$ of hydroquinone $(50 \mathrm{mM})$, $700 \mu \mathrm{l}$ of $\mathrm{K}-\mathrm{Na}$ phosphate buffer pH $6.6(100 \mathrm{mM})$ and $100 \mu \mathrm{l}$ of crude extract in a total volume of $1 \mathrm{ml}$ (Zaborina et al. 1995). One unit of enzyme activity was defined as the amount of enzyme required to generate $1 \mu \mathrm{mol}$ of product per minute. Protein concentrations of the crude extract from different inducer-cultured bacteria were determined by the Bradford method using bovine serum albumin (Bradford 1976).
Chemicals

2-nitrophenol, 3-nitrophenol, 4-nitrophenol were obtained from Merck AG, Darmstadt, Germany. 4-Hydroxybenzoic acid and protocatechuic acid were obtained from FLUKA, Fluka AG, Buchs, Switzerland. Benzoic acid and other chemicals were of analytical quality and were obtained from local suppliers.

\section{Results and discussion}

Cometabolic degradation of nitrophenols by Stenotrophomonas maltophilia KB2

Within aromatic substrates produced in plants, terpenoids and phenolic compounds, as benzoic acids, are commonly known. These compounds, as secondary metabolites, are produced on the determined growth stage by specific plant tissues or organs (Ornston and Stanier 1966; Singer et al. 2003). They are usually located in leaves by which they enter the soil or are secreted directly into the soil by the root system (Singer et al. 2003). The most important source of these metabolites in soil is decay of plants tissues. Aromatic compounds of plant origin are easily transformed and, as it is known, stimulate bacteria to xenobiotics degradation.

In our studies on mononitrophenols degradation $3 \mathrm{mM}$ benzoate, 4-hydroxybenzoate, 3,4-dihydroxybenzoate as growth substrates were used. Because the ability of strain to metabolise high concentration of xenobiotic is desired quality, in our experiment $1 \mathrm{mM}$ of nitrophenols was used despite the fact that degradation of these substrates at lower concentration (0.05-0.74 mM) was observed (Chauhan et al. 2000; Qui et al. 2007; Walia et al. 2002).

Figure 1 shows that depending on cometabolic system KB2 strain was able to degrade from 0.15 to $0.6 \mathrm{mM}$ of mononitrophenol used after 14 days of cultivation. Moreover, presence of nitrophenols didn't inhibit degradation of carbon source. Increase of microbial biomass suggests resistance of KB2 strain to these substrates (Fig. 1). During 14 days of experiment only partial cometabolite degradation was observed. Nevertheless possible application of Stenotrophomonas maltophilia KB2 in natural environment could contribute to faster removal of nitroaromatics from degraded area as the bioremediation process takes a long time and the environment undergoes dynamic changes, accompanied by continuous influx of growth substrates.

Activity of ring cleavage dioxygenases after induction by various aromatic substrates

KB2 strain is known to synthesize various types of dioxygenases, both catechol and protocatechuate, depending on 

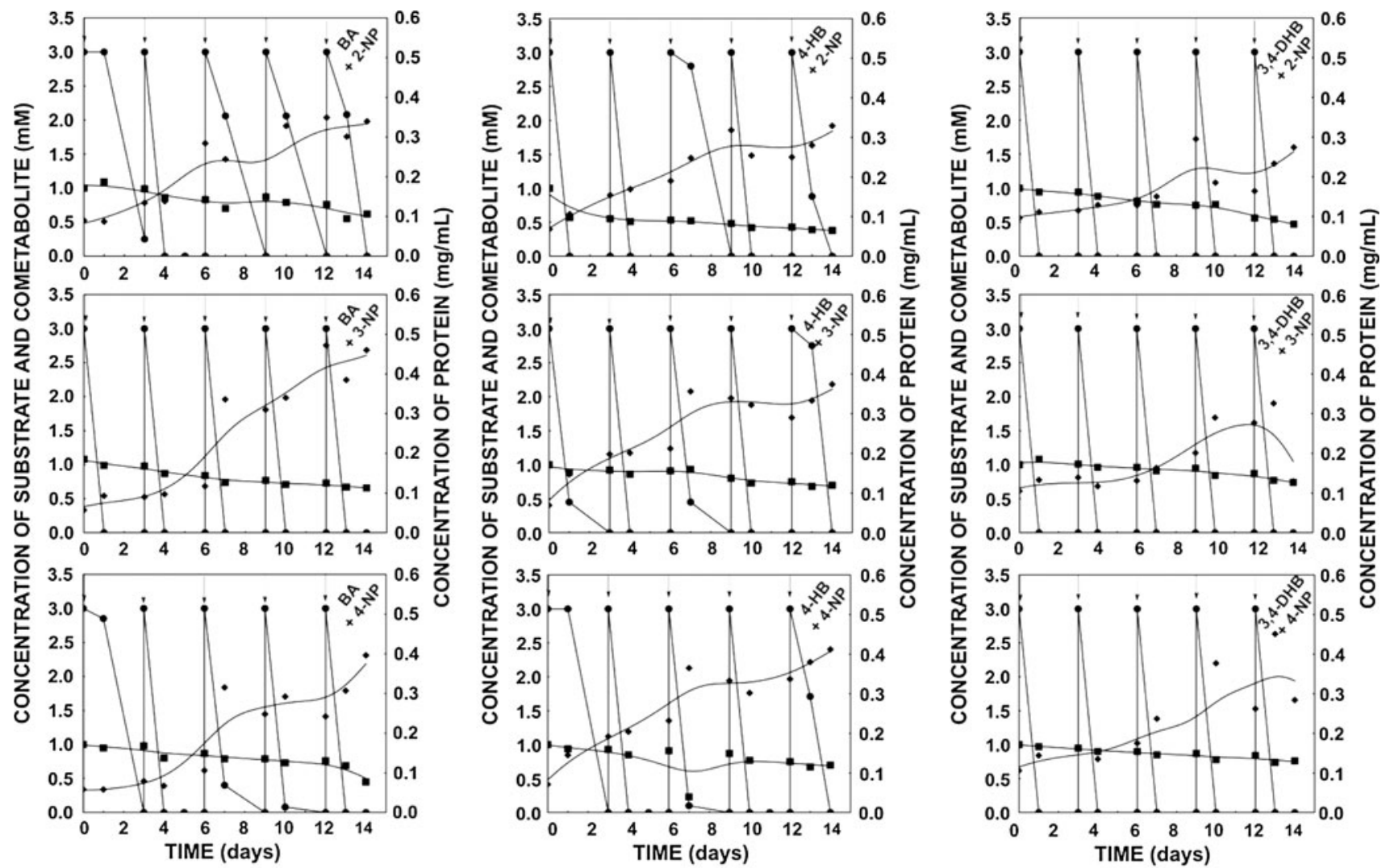

Substrate; $\mathbf{\square}$, Cometabolite; $\diamond$, Protein

Fig. 1 Cometabolic transformation of nitrophenols in the presence of aromatic compounds of plant origin (arrows indicate introduction of growth substrate into culture; BA-benzoic acid, 4-HB-4- hydroxybenzoic acid, 3,4-DHB-3,4-dihydroxybenzoic acid, 2-NP-2nitrophenol, 3-NP-3-nitrophenol, 4-NP-4-nitrophenol)

2008; Pakala et al. 2007). However activity of hydroquinone 1,2- dioxygenase in the crude enzyme extract of KB2 strain was not observed (Table 1). Activity of protocatechuate 4,5- dioxygenase observed after culturing of KB2 in the presence of 4-NP (Table 1), suggests lower sensitivity of protocatechuate dioxygenases to inhibitory effect of mononitrophenols.

Presence of aromatic ring in the structure of natural phenolic compounds produced by plants (among them benzoic acids) induces synthesis of similar degradation enzymes as xenobiotics do. Such substrates usually are easily degraded by microorganisms according to the variety of degradation systems formed during evolution processes (Mendonca et al. 2004; Münzenberger et al. 2003; Sutherland et al. 1981). Because mononitrophenols were no degraded by KB2 in monosubstrate systems (Greń et al. 2010) we decided to introduce into cometabolic systems benzoic acid, 4-hydroxybenzoic acid and 3,4-dihydroxybenzoic acid. In the presence of 2-NP or 3-NP and 3,4DHB or 4-HB as a growth substrate activity of protocatechuate 3,4- dioxygenase was observed (Table 2), while in the culture with 4-NP activity of this enzyme was observed 
Table 1 Dioxygenases activity after induction by aromatic substrates (4-HB-4-hydroxybenzoic acid; 3,4-DHB-3,4-dihydroxybenzoic acid; HQhydroquinone; 2-NP-2-nitrophenol; 3-NP-3-nitrophenol; 4-NP-4-nitrophenol; the plus/minus values represent standard deviation)

\begin{tabular}{|c|c|c|c|c|c|}
\hline \multirow[t]{3}{*}{$\begin{array}{l}\text { Enzyme } \\
\text { Inductor }\end{array}$} & $\begin{array}{l}\text { Catechol 1, } \\
\text { 2-dioxygenase, } \\
\text { U/mg protein }\end{array}$ & $\begin{array}{l}\text { Catechol 2, } \\
\text { 3-dioxygenase, } \\
\text { U/mg protein }\end{array}$ & $\begin{array}{l}\text { Protocatechuate } 3 \text {, } \\
4 \text {-dioxygenase } \\
\mathrm{U} / \mathrm{mg} \text { protein }\end{array}$ & $\begin{array}{l}\text { Protocatechuate } 4, \\
5 \text {-dioxygenase } \\
\text { U/mg protein }\end{array}$ & $\begin{array}{l}\text { Hydroquinone } 1 \text {, } \\
2 \text {-dioxygenase, } \\
\text { U/mg protein }\end{array}$ \\
\hline & \multicolumn{5}{|c|}{ Substrate in reaction mixture } \\
\hline & Catechol & Catechol & 3,4-DHB & 3,4-DHB & HQ \\
\hline Phenol & $0.06 \pm 0.02$ & $4.92 \pm 0.34$ & $0.00 \pm 0.00$ & $0.00 \pm 0.00$ & ND \\
\hline 4-HB & $0.00 \pm 0.00$ & $0.00 \pm 0.00$ & $0.13 \pm 0.05$ & $0.00 \pm 0.00$ & ND \\
\hline 3,4-DHB & $0.00 \pm 0.00$ & $0.00 \pm 0.00$ & $0.46 \pm 0.13$ & $0.00 \pm 0.00$ & ND \\
\hline Benzoate & $11.97 \pm 0.34$ & $0.00 \pm 0.00$ & $0.00 \pm 0.00$ & $0.00 \pm 0.00$ & ND \\
\hline 2-NP & $0.29 \pm 0.13$ & $0.00 \pm 0.00$ & $0.00 \pm 0.00$ & $0.11 \pm 0.00$ & $0.00 \pm 0.00$ \\
\hline $3-\mathrm{NP}$ & $0.12 \pm 0.01$ & $0.00 \pm 0.00$ & $0.00 \pm 0.00$ & $0.00 \pm 0.00$ & $0.00 \pm 0.00$ \\
\hline 4-NP & $0.14 \pm 0.08$ & $0.01 \pm 0.00$ & $0.00 \pm 0.00$ & $0.73 \pm 0.00$ & $0.00 \pm 0.00$ \\
\hline
\end{tabular}

Table 2 Dioxygenases activity in cometabolic cultures (4-HB-4-hydroxybenzoic acid; 3,4-DHB-3,4-dihydroxybenzoic acid; 2-NP-2-nitrophenol; 3-NP-3-nitrophenol; 4-NP-4-nitrophenol; the plus/minus values represent standard deviation)

\begin{tabular}{|c|c|c|c|c|c|}
\hline \multicolumn{2}{|l|}{ Enzyme } & \multirow{2}{*}{\multicolumn{2}{|c|}{$\begin{array}{ll}\text { Catechol 1, } & \text { Catechol 2, } \\
2 \text {-dioxygenase, } & 3 \text {-dioxygenase, } \\
\text { U/mg protein } & \text { U/mg protein } \\
\text { Substrate in reaction mixture }\end{array}$}} & \multirow[t]{2}{*}{$\begin{array}{l}\text { Protocatechuate } 3, \\
4 \text {-dioxygenase } \\
\text { U/mg protein }\end{array}$} & \multirow[t]{2}{*}{$\begin{array}{l}\text { Protocatechuate } 4 \\
5 \text {-dioxygenase } \\
\text { U/mg protein }\end{array}$} \\
\hline \multicolumn{2}{|l|}{ Inductor } & & & & \\
\hline & & Catechol & Catechol & 3,4-DHB & 3,4-DHB \\
\hline \multirow[t]{3}{*}{ 2-NP } & 3,4-DHB & $0.00 \pm 0.00$ & $0.06 \pm 0.00$ & $1.06 \pm 0.12$ & $0.00 \pm 0.00$ \\
\hline & 4-HB & $0.01 \pm 0.00$ & $0.00 \pm 0.00$ & $0.09 \pm 0.00$ & $0.00 \pm 0.00$ \\
\hline & Benzoate & $0.01 \pm 0.00$ & $0.00 \pm 0.00$ & $0.00 \pm 0.00$ & $0.00 \pm 0.00$ \\
\hline \multirow[t]{3}{*}{$3-\mathrm{NP}$} & 3,4-DHB & $0.00 \pm 0.00$ & $0.00 \pm 0.00$ & $0.26 \pm 0.04$ & $0.00 \pm 0.00$ \\
\hline & 4-HB & $0.00 \pm 0.00$ & $0.00 \pm 0.00$ & $0.81 \pm 0.46$ & $0.00 \pm 0.00$ \\
\hline & Benzoate & $0.01 \pm 0.00$ & $0.00 \pm 0.00$ & $0.00 \pm 0.00$ & $0.00 \pm 0.00$ \\
\hline \multirow[t]{3}{*}{ 4-NP } & 3,4-DHB & $0.00 \pm 0.00$ & $0.23 \pm 0.00$ & $0.52 \pm 0.12$ & $0.00 \pm 0.00$ \\
\hline & 4-HB & $0.00 \pm 0.00$ & $0.00 \pm 0.00$ & $0.71 \pm 0.65$ & $0.00 \pm 0.00$ \\
\hline & Benzoate & $0.00 \pm 0.00$ & $0.33 \pm 0.00$ & $0.00 \pm 0.00$ & $0.00 \pm 0.00$ \\
\hline
\end{tabular}

only in the presence of 3,4-DHB (Table 2). Even though catechol 1,2- dioxygenase was not active and catechol 2,3dioxygenase was active only in the presence of 4-NP and 3,4-DHB or benzoate (Table 2), partial degradation of nitrophenols was observed in all cometabolic systems (Fig. 1). As isolation and determination of enzymes activity showed synthesis of protocatechuate dioxygenases by KB2 strain in the presence of nitroaromatics (Table 1) it seems very interesting to determine if such enzymes might take part in nitrophenols degradation, even though degradation of these compounds via protocatechuate pathway was not observed. As it is known aerobic degradation of mononitrophenols proceeds through benzenotriol (Cassidy et al. 1999; Pakala et al. 2007), substrate which has very similar structure to protocatechuate, except the presence of hydroxyl group at C1, instead of carboxyl one (Fig. 2). Additionally it is known that attack of protocatechuate dioxygenases on aromatic ring take place between $\mathrm{C} 3$ and

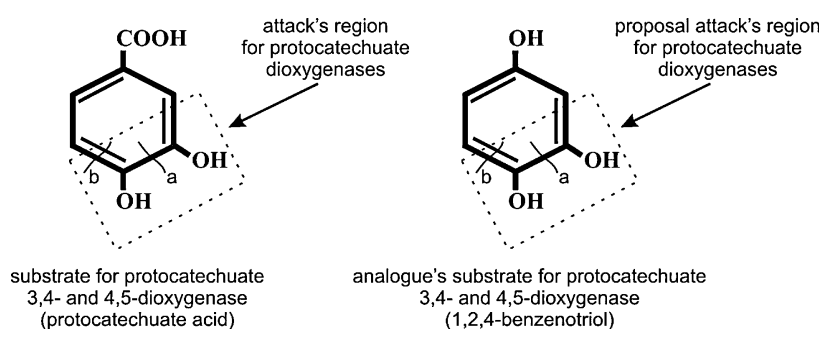

Fig. 2 Proposed region of attack of protocatechuic dioxygenases of KB2 strain (a the site of intradiol ring cleavage; $\mathbf{b}$ the site of extradiol ring cleavage)

C4 or C4 and C5 of catechol ring characteristic for both protocatechuate and benzenotriol (Vaillancourt et al. 2006). According to this knowledge we suggest that in cometabolite systems enzymes of protocatechuic acid degradation might be involved in degradation of benzenotriol formed in the consequence of mononitrophenols 
degradation. However presented assumptions need to be confirmed by appropriate kinetic parameters determination, especially determination of inhibition constant for aromatic acid/mononitrophenol system as similarity of above-mentioned substrates suggest possibility of their competition for enzyme active site.

\section{Conclusion}

Chemical diversity of contaminations introduced daily into natural environment is so huge that it is impossible to rule out the influence of simple as well as composite organic and inorganic compounds on dioxygenases activity. Because of that intensity of bioremediation processes proceed with the use of Stenotrophomonas maltophilia strain KB2 depends on the presence, availability and concentration of different aromatic substrates among them phenolic compounds of plant origin. Such substrates are not only very common in the environment but, as we have shown, induce different protocatechuate dioxygenases, enzymes that may be used in degradation of aromatic acids as well as other compounds with catechol structure. Although further research would be necessary to confirm our theory, wide substrate specificity of examined enzymes allows the use of Stenotrophomonas maltophilia strain KB2 for bioremediation of environments contaminated with different aromatic compounds.

Acknowledgments This work was funded by Polish Ministry of Science and Higher Education funded as a research project from grant-in-aid for scientific research in years 2007-2010. Authors would like to thank Agnieszka Materna for excellent technical assistance.

Open Access This article is distributed under the terms of the Creative Commons Attribution Noncommercial License which permits any noncommercial use, distribution, and reproduction in any medium, provided the original author(s) and source are credited.

\section{References}

Blasco R, Moore E, Wray V, Pieper D, Timmis K, Castillo F (1999) 3-Nitroadipate, a metabolic intermediate for mineralization of 2 , 4-dinitrophenol by a new strain of a Rhodococcus species. J Bacteriol 181:149-152

Bradford MM (1976) A rapid and sensitive method for the quantitation of microgram quantities of protein utilizing the principle of protein-dye binding. Anal Biochem 72:248-258

Cassidy MB, Lee H, Trevors JT, Zablotowicz RB (1999) Chlorophenol and nitrophenol metabolism by Sphingomonas sp UG30. J Industr Microbiol Biotechnol 23:232-241

Chauhan A, Samanta SK, Jai K (2000) Degradation of 4-nitrocatechol by Burkholderia cepacia: a plasmid-encoded novel pathway. J Appl Microbiol 88:764-772

Cho Y-G, Rhee S-K, Lee S-T (2000) Influence of phenol on biodegradation of $p$-nitrophenol by freely suspended and immobilized Nocardioides sp. NSP41. Biodegradation 11:21-28
Ebert S, Rieger PG, Knackmuss H-J (1999) Function of coenzyme $\mathrm{F}_{420}$ in aerobic catabolism of 2, 4, 6-trinitrophenol and 2, 4dinitrophenol by Nocardioides simplex FJ2-1A. J Bacteriol 181:2669-2674

Greń I, Wojcieszyńska D, Guzik U, Perkosz M, Hupert-Kocurek K (2010) Enhanced biotransformation of mononitrophenols by Stenotrophomonas maltophilia $\mathrm{KB} 2$ in the presence of aromatic compounds of plant origin. World J Microbiol Biotechnol 26:289-295

Guzik U, Greń I, Wojcieszyńska D, Łabużek S (2009) Isolation and characterization of a novel strain of Stenotrophomonas maltophilia possesing various dioxygenases for monocyclic hydrocarbons degradation. Braz J Microbiol 40:285-291

Hegeman GD (1966) Synthesis of enzymes of the mandelate pathways by Pseudomonas putida. Synthesis of enzyme by the wild type. J Bacteriol 91:1140-1154

Kieboom J, van den Brink H, Frankena J, de Bont JAM (2001) Production of 3-nitrocatechol by oxygenase-containing bacteria: optimization of the nitrobenzene biotransformation by Nocardia S3. Appl Microbiol Biotechnol 55:290-295

Leung KT, Tresse O, Errampalli D, Lee H, Trevors JT (1997) Mineralization of p-nitrophenol by pentachlorophenol-degrading Sphingomonas ssp. FEMS Microbiol Lett 155:107-114

Leung KT, Campbel S, Gan Y, White DC (1999) The role of the Sphingomonas species UG30 pentachlorophenol-4-monooxygenaze in $p$-nitrophenol degradation. FEMS Microbiol Lett 173:247-253

Mendonca E, Martins A, Anselmo A (2004) Biodegradation of natural phenolic compounds as single and mixed substrates by Fussarium flocciferum. J Biotechnol 7:30-37

Moonen MJH, Synowsky SA, van den Berg WAM, Westphal AH, Heck AJR, van den Heuvel RHH, Fraaije MW, van Berkel WJH (2008) Hydroquinone dioxygenase from Pseudomonas fluorescens ACB: a novel member of the family of nonheme-iron(II)dependent dioxygenases. J Bacteriol 190:5199-5209

Münzenberger B, Hammer E, Wray V, Schauer F, Schmidt J, Strack D (2003) Detoxification of ferulic acid by ectomycorrhizal fungi. Micorrhiza 13:117-121

Ornston LN, Stanier RY (1966) The conversion of catechol and protocatechuate and $\beta$-ketoadipate by Pseudomonas putida. J Biol Chem 241:3776-3780

Pakala SB, Gorla P, Pinjari AB, Krovidi RK, Baru R, Yanamandra M, Merrick M, Siddavattam D (2007) Biodegradation of methyl parathion and $p$-nitrophenol: evidence for the presence of a $p$-nitrophenol 2-hydroxylase in a gram-negative Serratia sp. strain DS001. Appl Microbiol Biotechnol 73:1452-1462

Peng X, Misawa N, Harayama S (2003) Isolation and characterization of thermophilic Bacilli degrading cinnamic, 4-coumaric and ferulic acid. Appl Environm Microbiol 69:1417-1427

Pitter P (1985) Correlation of microbial degradation rates with the chemical structure. Acta Hydrochim Hydrobiol 13:453-460

Qui X, Zhong Q, Li M, Bai W, Li B (2007) Biodegradation of p-nitrophenol by methyl parathion-degrading Ochrobactrum sp. B2. Int Biodet Biodegrad 59:297-301

Schenzle A, Lenke H, Fischer P, Williams PA, Knackmuss H-J (1997) Catabolism of 3-nitrophenol by Ralstonia eutropha JMP134. Appl Environ Microbiol 63:1421-1427

Singer AC, Crowley DE, Thompson IP (2003) Secondary plant metabolites in phytoremediation and biotransformation. Trends Biotechnol 21:123-130

Sparnins VL, Dagleys A (1975) Alternative routes of aromatic catabolism in Pseudomonas acidovorans and Pseudomonas putida: gallic acid as a substrate and inhibitor of dioxygenases. J Bacteriol 124:1374-1385

Stanier RY, Ingraham JL (1954) Protocatechuic acid oxidase. J Biol Chem 210:799-808 
Sutherland JB, Crawford DL, Pometto AL (1981) Catabolism of substituted benzoic acids by Streptomyces. Appl Environ Microbiol 41:442-448

Vaillancourt FH, Bolin JT, Eltis LD (2006) The ins and outs of ringcleaving dioxygenases. Crit Rev Biochem Mol Biol 41:241-267

Walia S, Shi L, Khan AA, Joshi B, Chaudry R (2002) Sequence analysis and molecular charazterization of a nitrocatechol dioxygenase gene from Pseudomonas putida. J Environ Sci Health B37:379-391
Wan N, Gu J-D, Yan Y (2007) Degradation of $p$-nitrophenol by Achromobacter xylosoxidans Ns isolated from wetland sediment. Int Biodeter Biodegrad 59:90-96

Zaborina O, Latus M, Eberspacher J, Golovleva LA, Lingens F (1995) Purification and characterization of 6-chlorohydroxyquinol 1, 2dioxygenase from Streptomyces rochei 303: comparison with an analogous enzyme from Azotobacter sp. Strain GP1. J Bacteriol 177:229-234 